\title{
Correlation Analysis of Factors Affecting Shoring Construction Techniques in Central Business District of Addis Ababa, Ethiopia
}

\author{
Hailemariam Kassu ${ }^{\# 1}$, Eyob Mekonnen ${ }^{\# 2}$, Dumesa Gudissa ${ }^{\# 3}$, Emer T. Quezon ${ }^{* \# 4}$ \\ \#1 Construction Technology and Management Department, School of Civil and Environmental Engineering, Ambo \\ University, Ambo, Ethiopia \\ \#*2 Construction Technology and Management Department, School of Civil and Environmental Engineering, Ambo \\ University, Ambo, Ethiopia \\ \#3 School of Civil \& Environmental Engineering, Ambo Institute of Technology, Ambo University, Ambo, Oromia \\ Region, Ethiopia \\ *\#4 Civil \& Construction Engineering and Management Streams, Ambo Institute of Technology, Ambo University, \\ Ambo, Oromia, Region, Ethiopia
}

\begin{abstract}
Recent urbanization of central parts of Addis Ababa has necessitated the use of deep excavations for the foundation of highrise buildings and related infrastructure projects. The conditions of the subsoil, the safety of neighboring structures, groundwater conditions, experience by contractors, working space, the effect of vibration, and noise must be considered for the choice of deep excavation support system. Besides, economic factors, local availability of equipment, and technical staff are also governing factors for choosing an appropriate shoring technique. The study focused on the major construction methods and techniques of shoring works in Addis Ababa, Ethiopia. Only four projects utilized shoring construction techniques from the total number of high-rise buildings available in the City. The target population included a minimum of twenty respondents from the four construction sites constructed around Beherawi, Lideta sub-city in Addis Ababa. Two of the projects were supervised by Specialists from Varnero Foundation and Meseret Foundation PLC. Primary and secondary data are gathered to support the objective of the study. All the frequency distribution, Reliability, and Pearson correlation were analyzed using SPSS. All groups of factors that affect shoring construction were ranked using the Relative Importance Index (RII). Results indicated that geotechnical investigation, building type, and excavation depth were the major factors with an RII value of 0.89 and $\mathbf{0 . 8 6}$, respectively. Besides, the analyses showed that were strong correlations between the different factors within each group of factors in undertaking the shoring construction. Hence, it is suggested to take a deep and detailed sub-soil investigation to determine the suitability of shoring materials, appropriate construction methods, and techniques.
\end{abstract}

Keywords - Deep Excavation, Foundation Work, Geological Nature, High-Rise Building, Shoring Technique.

\section{INTRODUCTION}

Urbanization is a trend that has been growing worldwide since the middle of the last century. Large metropolitan cities in Europe, North America, and the South East Asia region have evolved this trend. Fast population growth, limited land resources, high rise buildings, sophisticated and complex infrastructure needs have caused extra pressures for deep excavation underground construction. Environmental and social constraints such as limitations on noise levels, vibration, and soil movement in nearby or neighboring existing structures have been considered [1]. Addis Ababa was founded as Ethiopia's official capital city in 1886 by Emperor Menelik II and his wife, Empress Taytu Betul; the capital holds 527 square kilometers of the area of Ethiopia. Addis Ababa consists of 3,384,569, with a growth rate of $4.37 \%$, based on the 2007 census. The number may become inaccurate when recording and underestimated the city population, and the population is estimated to be around 4,793,699 in 2020 according to the world urbanization prospects. The population density of the City is estimated to be near 5,165 individuals per square kilometers available [2].

Throughout the century, the rural expansion is associated with movement and displacements of the population from the rural countryside areas to Addis Ababa were dramatically increased. It is associated with poverty issue and lack of infrastructure for an ever-increasing number of people; because of this and other factors, Addis Ababa experienced a considerable rise in land prices, the emergence of multi-story buildings as a norm with an increasing number of floors from two and three stories to higher buildings exceeding twenty stories. Due to land scarcity at these city centers, deep excavation for the underground construction of multiple basements is now normally considered [3].

When space is available, the most economical way to build a permanent basement is to construct an open cut excavation foundation. This requires a sufficient right to construct safe slopes and access to excavation, dewatering, and backfill construction expertise [4]. Limitations associated with an open cut solution typically happened in construction sites with restricted laydown areas far away from the building, restricted crane access, and dewatering problem. The latter is often associated with detrimental settlements of surrounding properties [5]. In the central business district area of Addis Ababa, particularly around "Senga Tera, Beherawi," several high-rise buildings are being constructed that needs a deep excavation for structural and functional purposes. As a result of these, it is important to practice shoring technology to protect the adjacent buildings and the surrounding soil from possible collapse.

Shoring renders a support system for trench faces to prevent soil movement, underground utilities, roadways, and foundations. Shoring is used when the cut's location or depth makes sloping back to the maximum allowable slope impractical and within a 
confined space. Shoring design can be a challenging task. The designer has to contend with many unknowns and factors that influence the excavation shoring [6]. Due to the construction industry's different emerging technology and complexity, many infrastructures become high-rise building and high way pavement. Much of those structures were constructed around the CBD area of Addis Ababa. Most of the CBD areas are confined and densely populated. For this reason, it is difficult to have a large plot of land to construct those high-rise buildings. Moreover, the excavation is being conducted with a small land plot using slope bracing as a conventional system, leading to damage to adjacent buildings, highway, and Underground utilities. Hence the use of shoring technology to solve these problems is highly valuable.

However, in Ethiopia, shoring work is generally performed with a small number of specialized firms in foundation work. However, the need for advanced technology, technique, cost, and higher demand comes from the fast-growing building construction project. Due to this case, those involved in shoring work may suffer capacity problems to cover the whole project, making the project delay and fail. Considering these problems, the study investigates the main factors and challenges the local firms faced to adapt to this Ethiopia technique.

\section{RESEARCH METHODS}

\section{A. Study Area}

Addis Ababa is Ethiopia's capital city and found in the western margin of the Ethiopian Rift valley. Its geographical coordination is 90 0' 19.4436" N, 380 45' 48.9996" E and 2355m above sea level. The study area has been located under "Lideta sub-city" around "Beherawi," Addis Ababa, Ethiopia [7].

\section{B. Sample Size and Selection}

The purposive sampling method was utilized in selecting construction sites. The samples were purposively selected from the Addis Ababa construction sites. Now a day the construction sites found in the town is mostly high rise building. Besides, only three licensed foundations specialists have been practicing the shoring construction technique in Ethiopia. Due to the above reason, all respondents were taken from four construction sites, which was being constructed under three construction firms, two under anchor foundation specialists, one under the Varnero foundation. In contrast, the remaining is from Meseret construction firms.

In the case of the research population, it did not mean that all stakeholders are possible respondents for the questionnaire. Rather the questionnaire was distributed to engineers \& other professionals who know the concerned construction projects during the specified time.

The minimum number of respondents is calculated based on Slovin's sampling formula (Yemane, 1967).

$$
\mathrm{n}=\frac{\mathrm{N}}{1+\mathrm{N}(\mathrm{e})^{2}}
$$

Where: $\mathrm{n}$ is the sample size

$\mathrm{N}$ is the population size

e error margin / margin of error, a 95\% confidence level was taken and e $=0.05$

So, for 25 stakeholder's respondents: $\mathrm{n}=20$ is taken

\section{Data Collection Process}

The study has used a different data source to attain its objective. In connection with this, Literature reviews were conducted to develop a conceptual foundation for the study. Simultaneously, through the literature reviews, the research questions were identified. The literature review provided the questionnaire and interview design root, distributed to professionals involved in the construction companies. A questionnaire is designed based on the literature review's collected data considering various factors that affect shoring construction in the deep excavation. Similarly, secondary data sources were collected based on the case study on Ethiopia's different shoring work techniques. Correspondingly, it is used as a reference and as an input to assess the current trend. Lastly, a desk study on case studies, questionnaires, interview, and field survey has been cross-checked to obtain the required result

\section{Data Analysis}

The results of the questionnaires are analyzed using statistical techniques. All the frequency distribution, Reliability, and Pearson correlation were conducted using SPSS [8]. All groups of factors (i.e., variables) that affect shoring construction were ranked using the relative importance index (RII).

The data were analyzed through statistical tools such as:

\section{i. $\quad$ Statistical Package for Social Science (SPSS)}

According to the contributing level, the questionnaires were prepared based on the Likert scale of five ordinal measures from 1 to 5 (very low effect to very high effect [9]. Frequency distribution, which shows the frequencies of observation of each response to each variable, was investigated using SPSS and used to analyze some questions. The level of measurement must be ordinal 
scales. The ordinal scale is a ranking or rating data that normally use integers in increasing or decreasing order. The numbers are assigned to the agreement or degrees of influence (1, 2, 3, 4, and 5) do not indicate that the intervals between scales are equal, nor do they indicate absolute quantities. They are merely numerical labels. Based on this scale, the researcher has the following table:

TABLE I

A RATING SCALE FOR A SIGNIFICANT LEVEL OF FACTORS

\begin{tabular}{|c|l|l|l|l|l|}
\hline $\begin{array}{c}\text { Significance } \\
\text { Level }\end{array}$ & $\begin{array}{l}\text { Extremely } \\
\text { Significant }\end{array}$ & $\begin{array}{l}\text { Very } \\
\text { Significant }\end{array}$ & $\begin{array}{l}\text { Moderately } \\
\text { Significant }\end{array}$ & $\begin{array}{l}\text { Slightly } \\
\text { significant }\end{array}$ & $\begin{array}{l}\text { Not } \\
\text { Significant }\end{array}$ \\
\hline Scale & 5 & 4 & 3 & 2 & 1 \\
\hline
\end{tabular}

Likert scale is important to know respondents' feelings or attitudes about something and is utilized for the data analysis. The respondents must indicate how closely their feelings match with the question or statement on a rating scale.

$$
\begin{aligned}
& \mathrm{MS}=\frac{\sum[f * S]}{N} \\
& \text { Where: } \\
& \text { MS = Mean Score } \\
& \mathrm{f}=\text { Frequency of responses for each scores. } \\
& \mathrm{S}=\text { Scores given to each factor. } \\
& \mathrm{N}=\text { Total No. of responses concerning each factor }
\end{aligned}
$$

One of the most common methods used to measure the relationship between variables is Spearman Rank's Correlation Coefficient method and Pearson's correlation. In this study, Pearson's correlation method is used since it's often used to evaluate relationships involving ordinal values.

ii. $\quad$ Relative Importance Index (RII)

The contribution of each of the factors to overall delays was examined, and the ranking of the attributes in terms of their criticality as perceived by the respondents was done by use of Relative Importance Index (RII), which was computed using an equation and the results of the analysis are presented in Tables. To determine the ranking of different factors from respondents' viewpoint, the Relative Importance Index (RII) was computed using the Equation below [10].

$$
\begin{aligned}
& \mathrm{RII}=\frac{\sum W}{(A X N)} . \\
& \text { Where: }
\end{aligned}
$$

Finally, after the questionnaires' results were analyzed using statistical techniques, it is used to form recommendations for further research. This was followed by thorough discussions to draw a conclusion and forward recommendations based on the study's findings.

\section{RESULTS AND DISCUSSION}

\section{A. Assessment on Current Shoring Construction Techniques}

In this part of the study, the study found out the current trend on shoring construction in line with the first specific objective. Case studies were collected from four building construction projects in the CBD areas of Addis Ababa, Ethiopia, those have been under execution from the year 2010 E.C. to 2012 E.C. The data were collected from archival documents, Discussion with participants on the project site, and data from the parties conducting the shoring work.

The following information was gathered from the open-ended questionnaires distributed to the stakeholders in the study area. This subtitle of the study is described like the steps used to carry out shoring construction.

\section{A.1 Drill and Pour Concrete into Shoring Pile}

After soil investigation and design, the first activity is drilling and casting a pile into excavation depth around the proposed site's perimeter. The steps to undertake the process are: Adjust the piling machine on the pile axis and haul with the auger to the drilling place \& Start drilling until the auger is filled, Swing to the uploading area, then Swing back to the top of the hole after that Repeat the above two steps until the pile is completely drilled, start erecting rebar cage using a crane using a funnel for dry method and tremie for wet method start pouring the concrete into the shoring pile care must be taken to avoid segregation and Finally, after this process completed and the concrete cure, start excavation. 
TABLE II

BAR DIAMETER AND SPACING OF ANCHOR PILES

\begin{tabular}{|c|c|c|}
\hline Parameter & Frequency & Percentage \\
\hline \multicolumn{3}{|c|}{ Diameter $\left(\mathbf{c m}^{\mathbf{2}}\right)$} \\
\hline 60 & 6 & $30 \%$ \\
\hline 70 & 4 & $20 \%$ \\
\hline 80 & 10 & $50 \%$ \\
\hline \multicolumn{3}{|c|}{ Spacing $(\mathbf{m})$} \\
\hline 1.50 & 4 & $20 \%$ \\
\hline 1.70 & 4 & $20 \%$ \\
\hline
\end{tabular}

From the above table, $50 \%$ of the respondents agree that the diameter of anchor piles should be $80 \mathrm{~cm}^{2}$, and 60 of them agree $1.80 \mathrm{~m}$ is enough for spacing in the study area.

i. Excavation

The second activity in shoring construction is excavation; it is carried out in a manner illustrated in the figure below to the excavation depth.

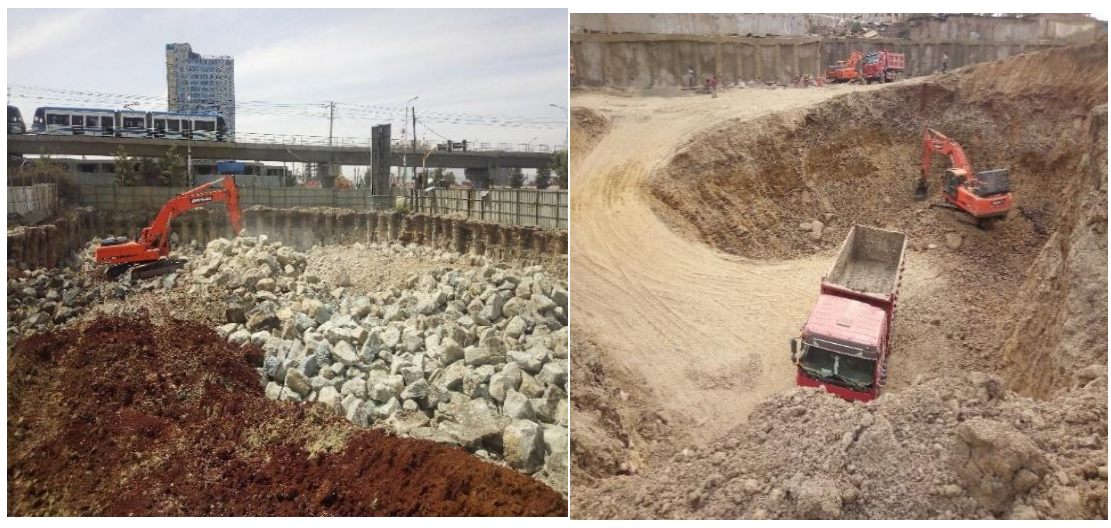

Figure 1: Excavation

ii. Tie back anchorage

Tie-back anchorage technique a general term in this technique drilling of piles, grouting, stressing is included. The inclination angle for drilling a pile varies as the nature of soil and depth of excavation change from the questionnaire survey.

TABLE III

TABLE 4. ANGLE OF INCLINATION FOR TIE BACK CONSTRUCTION

\begin{tabular}{|c|c|c|}
\hline Drilling Angle & Frequency & Percentage \\
\hline $20^{0}$ & 2 & $10 \%$ \\
\hline $25^{0}$ & 6 & $30 \%$ \\
\hline $30^{0}$ & 4 & $20 \%$ \\
\hline $35^{0}$ & 8 & $40 \%$ \\
\hline Total & $\mathbf{2 0}$ & $\mathbf{1 0 0 \%}$ \\
\hline
\end{tabular}

From the above table, $40 \%$ of the respondents execute their work with $35 \%$ the inclination angle. The recommended design standard of tie back is $10-40 \%$ of inclination, so all the results are within the standard.

iii. Mesh for Shotcrete

Reinforcing in Shotcrete is designed like conventional concrete, and bars must be sized and positioned to minimize interference with shotcreting. The common diameter of bars and spacing are summarized as follows based on the questionnaire survey. 
TABLE IV

BAR DIAMETER AND SPACING OF SHOTCRETE

\begin{tabular}{|l|c|c|}
\hline Parameter & Frequency & Percentage (\%) \\
\hline Diameter $\left(\mathbf{m m}^{\mathbf{2}}\right)$ & \multicolumn{2}{|c|}{} \\
\hline Horizontal Bars & \multicolumn{2}{|c|}{} \\
\hline 10 & 8 & $60 \%$ \\
\hline 12 & $\mathbf{2 0}$ & $\mathbf{1 0 \%}$ \\
\hline Total & \multicolumn{2}{|c|}{} \\
\hline Vertical Bars & 6 & $30 \%$ \\
\hline 8 & 14 & $70 \%$ \\
\hline 10 & $\mathbf{2 0}$ & $\mathbf{1 0 0 \%}$ \\
\hline Total & \multicolumn{2}{|c|}{} \\
\hline Spacing (cm) & 11 & $55 \%$ \\
\hline 1.50 & 5 & $25 \%$ \\
\hline 1.80 & 4 & $20 \%$ \\
\hline 2.00 & \multicolumn{3}{|c|}{} \\
\hline
\end{tabular}

\section{iv. Shotcrete Construction}

Shotcrete is the generic name for cement, sand, and fine aggregate concretes, which are applied pneumatically and compacted dynamically under high velocity by compressed air [11]. There are two techniques of shotcrete construction used in Ethiopia. These are:

- Wet-mix shotcrete

- Dry mix shotcrete

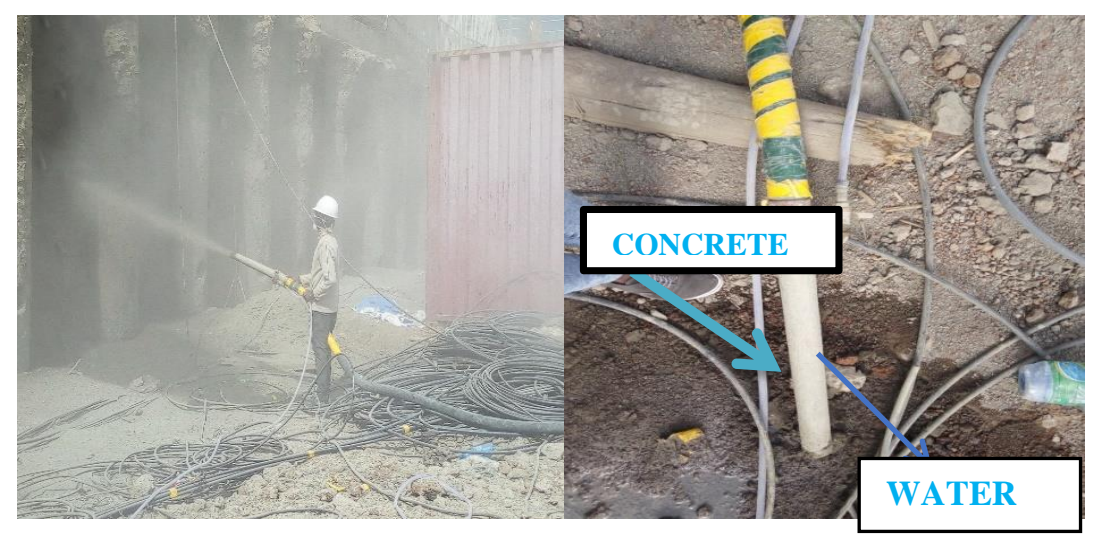

Figure 2: Wet and Dry shotcrete process

\section{B. Analysis of Factors Affecting Shoring Work Construction}

The results of this part of the study are directly related to the study's second specific objective. It includes the Reliability of research instruments based on SPSS scale analysis and combined Relative Importance Index (RII) of ranking factors affecting the shoring work construction during deep excavation. According to all and each participant's respectively and correlation coefficients between responses of the participants.

\section{B.1 Reliability of research instruments}

Reliability means consistency. It is the degree to which an instrument will give similar results for the same individuals at different times. It is the degree of uniformity of the results obtained from repeated measurements.

The data quality has been assured and measured through an internal validity instrument into correct research instruments to measure the variables during the data collection procedures. Besides, data consistency was checked using a reliability test (Cronbaches Alpha methods). According to Sekaran (2010), Reliability less than 0.6 is considered poor; those in the 0.7 range, acceptable, and those above 0.8 are good [12]. 
TABLE V

CRONBACH'S ALPHA COEFFICIENTS OF THE VARIABLES

\begin{tabular}{|c|c|c|c|}
\hline No. & Group of Factors & No. of Items & Cronbach's Alpha Coefficients \\
\hline 1 & Selection Criteria Factors & 5 & 0.712 \\
\hline 2 & Geotechnical Investigation & 4 & 0.763 \\
\hline 3 & Design & 7 & 0.806 \\
\hline 4 & Construction Techniques & 7 & 0.742 \\
\hline 5 & Economy & 4 & 0.708 \\
\hline
\end{tabular}

The table above indicated the value of the Cronbach's Alpha for the group of factors was above 0.7, which explains the scale's acceptability for further analysis.

\section{B.2 Shoring Type Selection Criteria}

In this category, around five factors were identified from the literature reviews that affect the shoring type selection process. Based on the Relative Importance Index (RII) and Pearson correlation value results, table VI and figure 3 displayed the results of participants' and RII and the rank of factors affecting the shoring type selection process.

TABLE VI

RANKED OF SELECTION CRITERIA FACTORS

\begin{tabular}{|c|c|c|c|c|c|c|c|c|}
\hline \multirow{2}{*}{ No. } & \multirow{2}{*}{ Factors } & \multicolumn{5}{|c|}{ Frequency } & \multirow{2}{*}{ RII } & \multirow{2}{*}{ Rank } \\
\hline & & 1 & 2 & 3 & 4 & 5 & & \\
\hline 1 & Subsoil Condition & 0 & 0 & 1 & 9 & 10 & 0.89 & 1 \\
\hline 2 & Depth of Excavation & 0 & 0 & 4 & 11 & 5 & 0.81 & 2 \\
\hline 3 & Space to a nearby structure & 0 & 0 & 9 & 10 & 1 & 0.71 & 3 \\
\hline 4 & Cost & 0 & 2 & 12 & 6 & 0 & 0.64 & 4 \\
\hline 5 & Technology & 0 & 8 & 10 & 2 & 0 & 0.54 & 5 \\
\hline
\end{tabular}

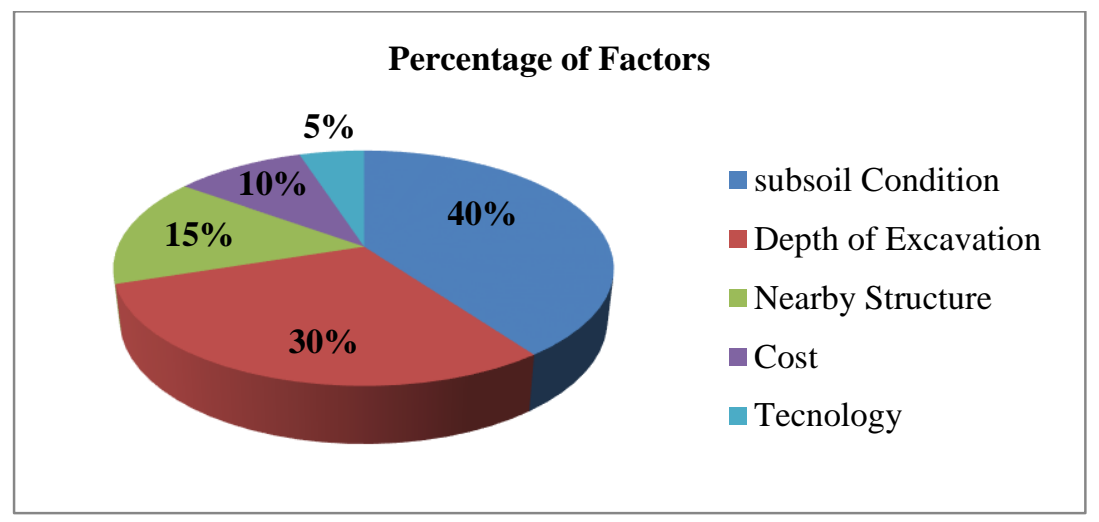

Figure 3: Selection criteria factors

Based on the combined Relative Important Index and ranking, as shown in figure 3, the critical and top-ranked factors considered during shoring type selection are discussed below.

Subsoil condition became the first main factor that extremely affected shoring type selection criteria with a relatively important index value of 0.89 . The nature of soil highly affects the type of shoring structure to be constructed on the proposed site. As the researcher describes in the literature part of the study, the selection process of earth retaining structures differs as soil layer changes. The excavation depth has been the second main factor that affects the shoring type's selection process extremely with a relatively important index value of 0.81 . This is because of the depth of excavation of a structure is governed by several factors, including the function and type of a building, Availability of excavation equipment, Availability of time. Because of this and other factors, excavation depths have highly affected the type and methods of shoring.

Nearby utilities and cost have been the third and fourth factors with a relative importance index value of 0.71 and 0.64 , respectively, and affect significantly. There is a higher demand for land for construction in most CBD areas, leading to a highrise building in small land plots. Excavation work in a small plot of land may seriously affect the stability of any portion of a building structure at or adjacent to the proposed excavation location, which can lead to structural failure or collapse. Costs of shoring work also affect the selection criteria because it is a machine intensive works which need expensive equipment to rent as well to own. 
Technology has been the last factor that affects moderately, with a relative importance index value of 0.54 . Shoring is a new technique of earth retaining structure in Ethiopia, and it needs advanced equipment, skilled labor that best feet with the techniques in which shoring requires. Generally, in this study, the nature of the soil, depth of excavation, space of nearby structures, cost, and technology affect the selection of excavation support systems.

\section{B.3. Geotechnical Factors}

A subsurface investigation is a process of collecting information and evaluating the site's conditions to design and construct the foundation for a structure, such as a building, roads, etc. The geotechnical site investigation's effort and detail are mandatory to obtain sufficient and correct site information to select and design a shoring structure.

Tables VII and VIII showed the participants' RII, the rank, and the Pearson correlation of geotechnical factors affecting the shoring structure.

In General, Pearson correlation or bivariate correlation is a statistic that provides a measurement of the linear correlation between two variables $\mathrm{X}$ and $\mathrm{Y}$. It has a value between +1 and -1 , where 1 is a total positive linear correlation, 0 is no linear correlation, and -1 is a total negative linear correlation [13].

\section{Relative importance index:}

TABLE VII

RANKED OF GEOTECHNICAL FACTORS

\begin{tabular}{|c|c|c|c|c|c|c|c|c|}
\hline \multirow{2}{*}{ No. } & \multirow{2}{*}{ Factors } & \multicolumn{5}{|c|}{ Frequency } & \multirow{2}{*}{ RII } & \multirow{2}{*}{ Rank } \\
\hline & & 1 & 2 & 3 & 4 & 5 & & \\
\hline 1 & Groundwater level & 0 & 0 & 3 & 12 & 5 & 0.82 & 2 \\
\hline 2 & Effect on nearby utilities & 1 & 2 & 9 & 6 & 2 & 0.66 & 3 \\
\hline 3 & Nature of soil & 0 & 0 & 0 & 6 & 12 & 0.84 & 1 \\
\hline 4 & $\begin{array}{l}\text { Water from the side of the } \\
\text { excavation }\end{array}$ & 0 & 4 & 13 & 2 & 1 & 0.60 & 4 \\
\hline
\end{tabular}

During the geotechnical investigation, the soil is ranked first with a relative importance index (RII) value of 0.84 . The main reason is obtaining information about the soil condition used to select the shoring wall's type and depth and angle of inclination for the tie-back anchors. The groundwater level is ranked second with an RII value of 0.82 . The groundwater level highly affects excavation depth and challenges the excavation process by incurring additional cost for continuous pumping. This process cause delay for the whole project life.

These two factors extremely affect the geological investigation, and great care must be taken when preparing a geotechnical analysis. Effect on nearby structure and water which comes from the side must be carefully investigated and ranked with an average RII value of 0.66 and 0.60 third and fourth, respectively. Excavation work must not be started until steps are taken to prevent the collapse or partial collapse of any potentially affected building or structure. Any excavation below the level of the footing of any structure, including retaining walls that could affect the structure's stability, must be assessed by a competent technical individual and secured by a suitable ground support system designed by an expert.

\section{Pearson correlation:}

TABLE VIII

PEARSON CORRELATION OF GEOTECHNICAL FACTORS

\begin{tabular}{|c|c|c|c|c|c|}
\hline \multicolumn{2}{|c|}{ Inter - Variables Correlation } & Groundwater & Nearby Utilities & Soil Nature & $\begin{array}{c}\text { Water from } \\
\text { side }\end{array}$ \\
\hline \multirow{3}{*}{ Groundwater } & Pearson correlation & 1 & 0.055 & 0.342 & $.523 *$ \\
\hline & Sig. (2. tailed) & & 0.846 & 0.212 & 0.018 \\
\hline & N. & 20 & 20 & 20 & 20 \\
\hline \multirow{3}{*}{ Nearby Utilities } & Pearson correlation & 0.055 & 1 & $0.721 * *$ & 0.049 \\
\hline & Sig. (2. tailed) & 0.846 & & 0.022 & 0.838 \\
\hline & N. & 20 & 20 & 20 & 20 \\
\hline \multirow{3}{*}{ Soil Nature } & Pearson correlation & 0.342 & $0.721 * *$ & 1 & 0.19 \\
\hline & Sig. (2. tailed) & 0.212 & 0.022 & & 0.421 \\
\hline & N. & 20 & 20 & 20 & 20 \\
\hline \multirow{3}{*}{ Water from side } & Pearson correlation & $.523 *$ & 0.049 & 0.19 & 1 \\
\hline & Sig. (2. tailed) & 0.018 & 0.838 & 0.412 & \\
\hline & $\mathrm{N}$. & 20 & 20 & 20 & 20 \\
\hline
\end{tabular}

**. Correlation is significant at the 0.01 level (2-tailed).

*. Correlation is significant at the 0.05 level (2-tailed). 
Table VIII showed how the group of factors interrelates or correlates and affects each other; this result is based on the SPSS Pearson correlation. Correlation analysis is used to measure the association (linear relationship) between two variables, only concerned with the relationship's strength.

Groundwater has a significant value of 0.018 with water from the side of the excavation. As the groundwater table increases, the challenges from the side of the excavated area also increase. The nature of soil and effect on nearby utility also linearly related to each other with a significant Pearson value of 0.022 . If the soil is weak, it leads to a shrink in volume and affects the nearby structure.

\section{B.4 Design Related Factors}

After evaluating site conditions and shoring selection criteria, the designer should determine if shoring is viable for the project based on the feasibility. The design methodology includes steps to determine the reinforcement members to resist bending moment and shear stresses. The soil-cement between the reinforcement members is considered the same way as lagging in traditional walls to resist and redistribute the horizontal stresses to the adjacent reinforcement. In this part, all the structural elements of the shoring wall are considered and analyzed based on the average RII value and Pearson correlation and ranked.

TABLE VIX

\section{RANKED OF THE DESIGN FACTORS}

\begin{tabular}{|c|c|c|c|c|c|c|c|c|}
\hline \multirow{2}{*}{ No. } & \multirow{2}{*}{ Factors } & \multicolumn{5}{|c|}{ Frequency } & \multirow{2}{*}{ RII } & \multirow{2}{*}{ Rank } \\
\hline & & 1 & 2 & 3 & 4 & 5 & & \\
\hline 1 & Diameter of anchor piles & 0 & 0 & 3 & 9 & 8 & 0.85 & 2 \\
\hline 2 & $\begin{array}{l}\text { Spacing between consecutive anchor } \\
\text { piles }\end{array}$ & 0 & 0 & 3 & 11 & 6 & 0.83 & 3 \\
\hline 3 & Height of anchor piles & 0 & 0 & 5 & 4 & 11 & 0.86 & 1 \\
\hline 4 & Diameter of rebar mesh & 0 & 2 & 8 & 7 & 3 & 0.71 & 4 \\
\hline 5 & Spacing of rebar mesh & 0 & 2 & 13 & 5 & 0 & 0.63 & 6 \\
\hline 6 & $\begin{array}{l}\text { Angle of inclination of tie-back } \\
\text { anchorage }\end{array}$ & 0 & 1 & 8 & 11 & 0 & 0.70 & 5 \\
\hline 7 & Percentage of stressing & 0 & 4 & 14 & 2 & 0 & 0.58 & 7 \\
\hline
\end{tabular}

The anchor pile height has been ranked in the first position, with an average RII value of 0.86 . This is because the height of anchor piles and depth of excavation is directly related, and if it is not carefully considered, it will cause a serious structural failure. The height of the wall increased with an increase in the displacement of the structure.

The diameter of anchor piles considered the second major factor affects the shoring work's design process by the Relative important index of 0.85 . An increase in the pile's diameter increases displacement near the wall's surface in $\mathrm{x}$ and $\mathrm{y}$ directions. The designer must give great care while designing those piles. Spacing between consecutive piles is ranked in the third position with a random importance index of 0.83 . Horizontal and vertical spacing of anchors were considered for this study. Decreasing the horizontal spacing can increase the anchor's stiffness per unit width; with high anchor stiffness, the anchor's compression will be quite small. The maximum deformation occurs near the excavation surface.

The diameter of shotcrete meshes and angle of inclination of tie-back anchors are ranked in the fourth and fifth with an average relative importance index of $0.71 \& 0.70$, respectively. These two factors affect shoring work because the meshes must be good enough to resist the soil's lateral load. The angle of inclination of tie back angel must be calculated carefully by considering the nearby utilities and excavation depth. The spacing of shotcrete mesh and percentage of stress affects the design processes moderately with RII value of 0.63 and 0.58 , respectively. This is because a machine does stress, and it has its own gauge to fix the process, and the bar's diameter also more governs the spacing.

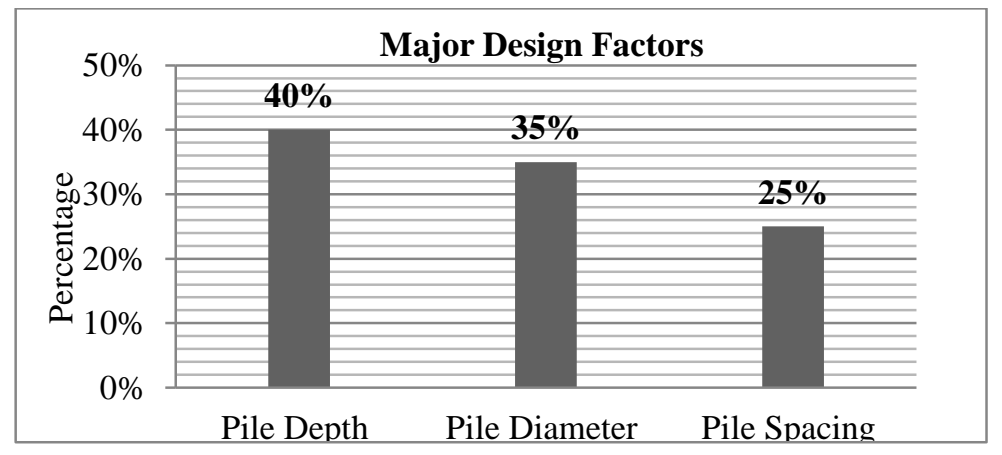

Figure 4: Major Design factor 


\section{Pearson Correlation}

TABLE X

PEARSON CORRELATION OF DESIGN FACTORS

\begin{tabular}{|c|c|c|c|c|c|c|c|c|}
\hline \multicolumn{2}{|c|}{$\begin{array}{l}\text { INTER - VARIABLES } \\
\text { CORRELATION }\end{array}$} & $\begin{array}{c}\text { Pile } \\
\text { Diameter }\end{array}$ & $\begin{array}{c}\text { Pile } \\
\text { Spacing }\end{array}$ & $\begin{array}{l}\text { Pile } \\
\text { Depth }\end{array}$ & $\begin{array}{c}\text { Mesh } \\
\text { Diameter }\end{array}$ & $\begin{array}{c}\text { Mesh } \\
\text { spacing }\end{array}$ & $\begin{array}{l}\text { Tie- } \\
\text { back }\end{array}$ & stress \\
\hline \multirow{3}{*}{$\begin{array}{c}\text { Pile } \\
\text { Diameter }\end{array}$} & Pearson correlation & 1 & $.575 * *$ & 0.382 & 0.104 & 0.094 & 0.182 & 0.332 \\
\hline & Sig. (2 tailed) & & 0.008 & 0.096 & 0.664 & 0.694 & 0.444 & 0.152 \\
\hline & N. & 20 & 20 & 20 & 20 & 20 & 20 & 20 \\
\hline \multirow{3}{*}{$\begin{array}{c}\text { Pile } \\
\text { Spacing }\end{array}$} & Pearson correlation & $.575 * *$ & 1 & $.554 *$ & 0.385 & 0.073 & 194 & 0.043 \\
\hline & Sig. (2 tailed) & 0.008 & & 0.011 & 0.094 & 0.758 & 0.413 & 0.858 \\
\hline & N. & 20 & 20 & 20 & 20 & 20 & 20 & 20 \\
\hline \multirow{3}{*}{ Pile Depth } & Pearson correlation & 0.382 & $.554 *$ & 1 & 0.323 & 0.114 & 0.201 & 0.176 \\
\hline & Sig. (2 tailed) & 0.096 & 0.011 & & 0.165 & 0.632 & 0.396 & 0.457 \\
\hline & $\mathrm{N}$. & 20 & 20 & 20 & 20 & 20 & 20 & 20 \\
\hline \multirow{3}{*}{$\begin{array}{c}\text { Mesh } \\
\text { Diameter }\end{array}$} & Pearson correlation & 0.104 & 0.385 & 0.323 & 1 & $.642 * *$ & $.538 * *$ & 0.011 \\
\hline & Sig. (2 tailed) & 0.664 & 0.094 & 0.165 & & 0.002 & 0.014 & 0.964 \\
\hline & N. & 20 & 20 & 20 & 20 & 20 & 20 & 20 \\
\hline \multirow{3}{*}{$\begin{array}{l}\text { Mesh } \\
\text { Spacing }\end{array}$} & Pearson correlation & 0.094 & 0.073 & 0.114 & $.642 * *$ & 1 & 0.074 & 0.049 \\
\hline & Sig. (2 tailed) & 0.694 & 0.758 & 0.632 & 0.002 & & 0.757 & 0.839 \\
\hline & N. & 20 & 20 & 20 & 20 & 20 & 20 & 20 \\
\hline \multirow{3}{*}{$\begin{array}{l}\text { Tie-back } \\
\text { angle }\end{array}$} & Pearson correlation & 0.182 & 0.194 & 0.201 & $.538 * *$ & 0.074 & 1 & 0.157 \\
\hline & Sig. (2. tailed) & 0.444 & 0.413 & 0.396 & 0.014 & 0.757 & & 0.509 \\
\hline & N. & 20 & 20 & 20 & 20 & 20 & 20 & 20 \\
\hline \multirow{3}{*}{$\begin{array}{l}\text { Percent of } \\
\text { stress }\end{array}$} & Pearson correlation & 0.332 & 0.043 & 0.176 & 0.011 & 0.049 & 0.157 & 1 \\
\hline & Sig. (2. tailed) & 0.152 & 0.858 & 0.457 & 0.964 & 0.839 & 0.509 & \\
\hline & N. & 20 & 20 & 20 & 20 & 20 & 20 & 20 \\
\hline
\end{tabular}

From the above table, the pile diameter and pile spacing, pile depth and pile spacing mesh diameter, and mesh spacing are significantly correlated with a Pearson correlation value of $0.008,0.011$, and 0.002 , respectively.

\section{B.5 Construction Technique Factors}

As the design completed, other challenge faces the shoring work, which is construction technique and environmental factors. Shoring is a new technology in the Ethiopia construction industry, and only limited firms engaged; it needs a more advanced workforce and equipment to execute the construction work. Table XI and figure 5 illustrate the number of factors that affect the construction process with RII and Pearson correlation analysis results.

TABLE XI

RANKED OF CONSTRUCTION TECHNIQUE FACTORS

\begin{tabular}{|c|c|c|c|c|c|c|c|c|}
\hline \multirow{2}{*}{ No. } & \multirow{2}{*}{ Factors } & \multicolumn{5}{|c|}{ Frequency } & \multirow{2}{*}{ RII } & \multirow{2}{*}{ Rank } \\
\hline & & 1 & 2 & 3 & 4 & 5 & & \\
\hline 1 & Site condition and access to the site & 0 & 0 & 6 & 13 & 1 & 0.75 & 4 \\
\hline 2 & Lack of training & 0 & 0 & 3 & 6 & 11 & 0.88 & 1 \\
\hline 3 & Poor communication & 0 & 0 & 10 & 9 & 1 & 0.71 & 6 \\
\hline 4 & Season & 0 & 0 & 3 & 9 & 8 & 0.85 & 2 \\
\hline 5 & Health and safety & 0 & 0 & 7 & 13 & 0 & 0.73 & 5 \\
\hline 6 & Lack of experience & 0 & 0 & 5 & 11 & 4 & 0.79 & 3 \\
\hline 7 & Corrosion & 0 & 8 & 11 & 1 & 0 & 0.53 & 7 \\
\hline
\end{tabular}


Lack of training or skilled labor, season, and experience are the major factors that extremely affect the construction process of shoring work with a random importance index of $0.88 \& 0.85$. This is because shoring is a new technology, and it needs more advanced and huge equipment and skilled operator for drilling and shotcrete purposes. As a result of this, continuous training and experience sharing is mandatory. The weather condition or season is the most significant factor that affects all excavation and shoring work. So the stockholders must schedule the work in a dry season.

Experience is directly related to the training of workforce; most of the construction workers have experience with ordinary construction work like concreting, mason, or carpeting but have not any related experience in shoring work, so they need continuous training and experience sharing.

Access to the site, health and safety, and poor communication are factors that highly affect the construction process of shoring work in the CBD area of Addis Ababa ranked fourth, fifth, and six with an average RII value of 0.79, 0.75, and 0.71, respectively. Condition and location of the site are the major factors because the construction process was executed in a confined and congested location (i.e., CBD area). It is difficult to access the site to load and unload materials like excavated materials and also equipment. Excavation in a deep more than $20 \mathrm{~m}$ deep is the most dangerous activity, so health and safety or assurance to the workers and also equipment must be considered. Communication also affected highly good communication between owner, consultant, and contractor and was mandatory to minimize cost overran, time delay, and dispute.

Corrosion is the last factor that slightly affects shoring work with a Relative Importance Index of 0.53 . This is because all the steel structures are covered with concrete, and even the tie-back rad also has a cover, so; all the components are safe from corrosion.

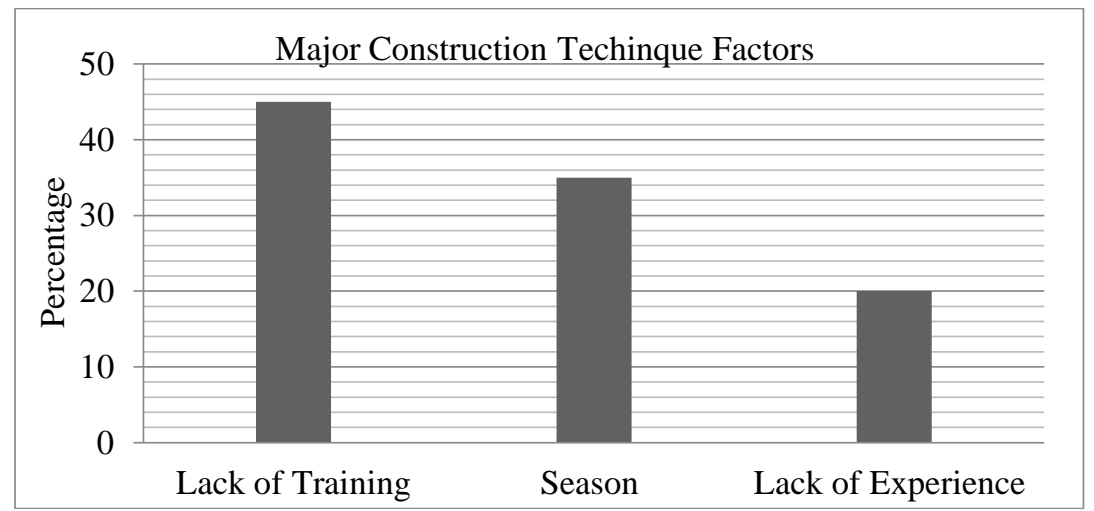

Figure 5: Construction Technique Factors

\section{Pearson Correlation}

TABLE XII

PEARSON CORRELATION OF CONSTRUCTION TECHNIQUE FACTORS

\begin{tabular}{|c|c|c|c|c|c|c|c|c|}
\hline \multicolumn{2}{|c|}{$\begin{array}{c}\text { Inter - Variables } \\
\text { Correlation }\end{array}$} & $\begin{array}{l}\text { Access } \\
\text { to site }\end{array}$ & Training & communication & Season & $\begin{array}{l}\text { Health } \\
\& \\
\text { Safety }\end{array}$ & Experience & Corrosion \\
\hline \multirow{3}{*}{ Access to site } & Pearson correlation & 1 & 0.131 & 0.435 & 0.119 & $0.44 *$ & 0.105 & 0.204 \\
\hline & Sig. (2 tailed) & & 0.581 & 0.055 & 0.618 & 0.052 & 0.661 & 0.389 \\
\hline & N. & 20 & 20 & 20 & 20 & 20 & 20 & 20 \\
\hline \multirow{3}{*}{ Training } & Pearson correlation & 0.131 & 1 & 0.119 & 0.024 & 0.266 & 0.063 & 0.468 \\
\hline & Sig. (2 tailed) & 0.581 & & 0.616 & 920 & 0.257 & 0.791 & 0.038 \\
\hline & N. & 20 & 20 & 20 & 20 & 20 & 20 & 20 \\
\hline \multirow{3}{*}{ communication } & Pearson correlation & 0.435 & 0.119 & 1 & 0.424 & 0.507 & 0.437 & $.571 * *$ \\
\hline & Sig. (2 tailed) & 0.055 & 0.616 & & 0.062 & 0.023 & 0.054 & 0.009 \\
\hline & $\mathrm{N}$. & 20 & 20 & 20 & 20 & 20 & 20 & 20 \\
\hline \multirow{3}{*}{ Season } & Pearson correlation & 0.119 & 0.024 & 0.424 & 1 & 0.027 & $.564 * *$ & 0.274 \\
\hline & Sig. (2 tailed) & 0.618 & 0.92 & 0.062 & & 0.911 & 0.01 & 0.242 \\
\hline & N. & 20 & 20 & 20 & 20 & 20 & 20 & 20 \\
\hline \multirow{3}{*}{$\begin{array}{l}\text { Health \& } \\
\text { Safety }\end{array}$} & Pearson correlation & $0.44 *$ & 0.266 & 0.507 & 0.027 & 1 & 0.212 & 0.101 \\
\hline & Sig. (2 tailed) & 0.052 & 0.257 & 0.023 & 0.911 & & 0.371 & 0.673 \\
\hline & N. & 20 & 20 & 20 & 20 & 20 & 20 & 20 \\
\hline \multirow[b]{2}{*}{ Experience } & Pearson correlation & 0.105 & 0.603 & 0.437 & $.564 * *$ & 0.212 & 1 & 0.438 \\
\hline & Sig. (2 tailed) & 0.661 & 0.791 & 0.054 & 0.1 & 0.371 & & 0.054 \\
\hline
\end{tabular}




\begin{tabular}{|l|l|c|c|c|c|c|c|c|}
\hline & N. & 20 & 20 & 20 & 20 & 20 & 20 & 20 \\
\hline \multirow{3}{*}{ Corrosion } & Pearson correlation & 0.204 & 0.468 & $0.571 * *$ & 0.274 & 0.101 & 0.438 & 1 \\
\cline { 2 - 9 } & Sig. (2 tailed) & 0.389 & 0.038 & 0.009 & 0.242 & 0.673 & 0.054 & 20 \\
\cline { 2 - 9 } & N. & 20 & 20 & 20 & 20 & 20 & 20 \\
\hline
\end{tabular}

Table XII displayed the Pearson correlation of construction-related factors access to the site is linearly related to health and safety with a significance value of 0.05 . Experience with a significance value of 0.1 . This is because as the access to site and space availability decrease, it will increase the workers' percentage of risk and even damage to equipment.

\section{B.6 Cost Related Factors}

From the questionnaire distributed to the stakeholders, $100 \%$ of the respondent agrees that shoring work is expensive, with different percentage costs per the project's total cost as illustrated in table XIII below.

TABLE XIII

COST IN PERCENTAGE FROM THE TOTAL COST OF PROJECT

\begin{tabular}{|l|c|c|}
\hline \multicolumn{1}{|c|}{ Percentage of Cost } & Frequency & Percentage \\
\hline $3 \%$ & 2 & $10 \%$ \\
\hline $4 \%$ & 6 & $30 \%$ \\
\hline $5 \%$ & 10 & $50 \%$ \\
\hline $10 \%$ & 2 & $10 \%$ \\
\hline Total & $\mathbf{2 0}$ & $\mathbf{1 0 0 \%}$ \\
\hline
\end{tabular}

From the above table, $50 \%$ of the respondent agreed that shoring work consumed $5 \%$ of the total work budget. The cost of shoring work is directly related to the cost of equipment, availability of equipment, a limited number of firms, and laboratory material. Table XIV ranked and correlated several factors based on the RII value of each factor.

TABLE XIV

\section{RANKED OF COST FACTORS}

\begin{tabular}{|r|l|c|c|c|c|c|c|c|}
\hline \multirow{2}{*}{ No. } & \multicolumn{2}{|c|}{ Factors } & \multicolumn{9}{c|}{ Frequency } & \multirow{2}{*}{ RII } & \multirow{2}{*}{ Rank } \\
\cline { 3 - 7 } & & $\mathbf{1}$ & $\mathbf{2}$ & $\mathbf{3}$ & $\mathbf{4}$ & $\mathbf{5}$ & & \\
\hline 1 & Cost of equipment's & 0 & 0 & 6 & 11 & 3 & 0.77 & 2 \\
\hline 2 & Availability of Resources & 0 & 2 & 11 & 6 & 1 & 0.66 & 3 \\
\hline 3 & A limited number of firms & 0 & 0 & 3 & 15 & 2 & 0.79 & 1 \\
\hline 4 & Laboratory materials & 0 & 7 & 9 & 4 & 0 & 0.57 & 4 \\
\hline
\end{tabular}

A limited number of competent firms ranked in the first position with a relative importance index value of 0.79 . This is because Addis Ababa is one of the cities that are registering rapid growth globally. The city construction sector also shows a fast growth in which many residential, commercial, and mixed-use buildings have been built for over a decade. Especially in CBD areas where a high rise building is built, shoring work is mandatory. Besides the regulation, the number of firms specializing in shoring work has the inability to cover the demand that comes from the fast growth of the building construction sector. And their limited number creates a non-competent market at work. It adds a great burden on those firms without upgrading the capacity to cover and run the ongoing projects properly. This may direct to an increase in cost and delay at the time of the project.

The cost of equipment and resource availability is ranked in the second and third with an average Relative Importance Index of $0.77 \& 0.66$. Shoring is a machine intensive work, and equipment used for this technique are too expensive to own and rent. The availability of resources like a skilled workforce to operate and fix those machines is another factor that plays a significant role in the project's economy. The last factor is the laboratory's availability, and the cost ranked fourth and moderately affects the project's cost with a random importance index value of 0.57 . This is because only tensile for steel and concrete test was conducted, which is common as other ordinary concrete construction. 


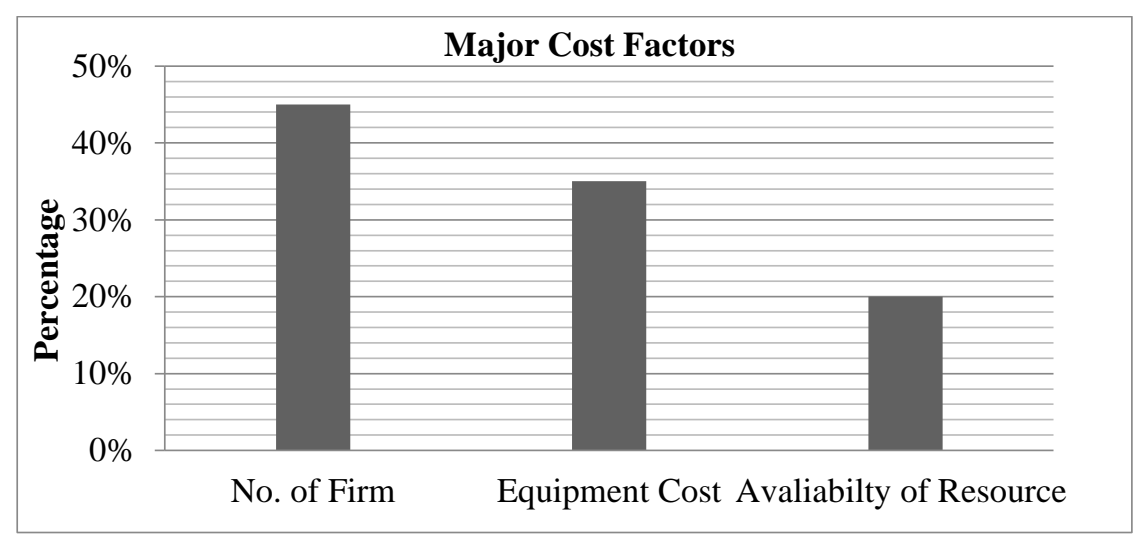

Figure 6: Major Cost Factors

\section{Pearson Correlation}

TABLE XV

RII RANK OF COST FACTORS

\begin{tabular}{|c|c|c|c|c|c|}
\hline \multicolumn{2}{|c|}{ Inter - Variables } & Equipment Cost & $\begin{array}{c}\text { Resource } \\
\text { Availability }\end{array}$ & No. of Firms & Laboratory \\
\hline \multirow{3}{*}{$\begin{array}{l}\text { Equipment } \\
\text { Cost }\end{array}$} & Pearson correlation & 1 & 0.203 & 0.131 & $0.479 *$ \\
\hline & Sig. (2 tailed) & & 0.39 & 0.583 & 0.033 \\
\hline & N. & 20 & 20 & 20 & 20 \\
\hline \multirow{3}{*}{$\begin{array}{l}\text { Resource } \\
\text { Availability }\end{array}$} & Pearson correlation & 0.203 & 1 & $.605 * *$ & 0.106 \\
\hline & Sig. (2 tailed) & 0.39 & & 0.005 & 0.656 \\
\hline & N. & 20 & 20 & 20 & 20 \\
\hline \multirow{3}{*}{ No. of Firms } & Pearson correlation & 0.131 & $.605 * *$ & 1 & 0.021 \\
\hline & Sig. (2 tailed) & 0.583 & 0.005 & & 0.931 \\
\hline & $\mathrm{N}$. & 20 & 20 & 20 & 20 \\
\hline \multirow{3}{*}{ Laboratory } & Pearson correlation & $.479 *$ & 0.106 & 0.021 & 1 \\
\hline & Sig. (2 tailed) & 0.033 & 0.656 & 0.931 & \\
\hline & N. & 20 & 20 & 20 & 20 \\
\hline
\end{tabular}

Table XV showed how the group of cost factors interrelates or correlates and affects each other; this result is based on SPSS Pearson correlation cost of equipment has a significant value of 0.033 with laboratory cost. A limited number of firms engage in shoring work, also linearly related to a resource with a significant Pearson value of 0.005 . When we see the number of firms within the market demand, it shows a shortage of firms. The number of specialized professional and construction firms on soil protection (shoring) work is limited and leads to cost overrun and time delay.

\section{B.7 Summary of Factors Affecting Shoring Work}

Based on the above discussions, the researcher prepares a group of factors to determine which group of factors highly affects shoring work construction in the study area and filled by the respondent and measured spastically. There were twenty-two key factors that are grouped under five group factors. Table XVI and figure 7 clearly presented the rank of this group of factors.

TABLE XVI

RANKED OF GROUP OF FACTORS

\begin{tabular}{|c|c|c|c|c|c|c|c|c|}
\hline \multirow{2}{*}{ No. } & \multirow{2}{*}{ Factors } & \multicolumn{5}{|c|}{ Frequency } & \multirow{2}{*}{ RII } & \multirow{2}{*}{ Rank } \\
\hline & & 1 & 2 & 3 & 4 & 5 & & \\
\hline 1 & Geotechnical investigation & 0 & 0 & 2 & 7 & 11 & 0.89 & 1 \\
\hline 2 & Design & 0 & 0 & 5 & 15 & 0 & 0.75 & 3 \\
\hline 3 & Construction Technique & 0 & 1 & 10 & 9 & 0 & 0.68 & 5 \\
\hline 4 & $\begin{array}{l}\text { Building type and depth of } \\
\text { excavation }\end{array}$ & 0 & 0 & 3 & 8 & 9 & 0.86 & 2 \\
\hline
\end{tabular}




\begin{tabular}{|l|l|c|c|c|c|c|c|c|}
\hline 5 & Economy & 0 & 0 & 8 & 12 & 0 & 0.72 & 4 \\
\hline 6 & Environmental and safety factors & 0 & 1 & 14 & 5 & 0 & 0.64 & 6 \\
\hline
\end{tabular}

The group of factors ranked first is a geotechnical investigation of the proposed site with a Relative Importance Index (RII) of 0.89. The purpose of a geotechnical investigation is to obtain information used to select the wall's type and depth, estimate earth pressures, locate the groundwater level, estimate settlements, the nature of soil by each layer of excavation, and distance from nearby structures through identifying the possible construction problems. So the good geotechnical investigation is the first critical factor to be considered during shoring work.

Building type and depth of excavation is the second major factor, with an average RII value of 0.86 . The depth of excavation is governing and interrelated with different factors. Some of the factors to be considered when the stakeholders discuss the depth of excavation is listed below:

- Function: the building is supposed to have four basement space levels, which is expected to involve excavation of up to $20 \mathrm{~m}$ of overburden.

- Geological and Geotechnical Conditions: the shear strength and compressibility characteristics of formation immediately below the mandatory excavation and extending to the foundation pressure's depth of influence are important factors determining the structure's stability.

- Availability of excavation equipment: the choice between deep and shallow excavation depends on equipment availability for drilling piles holes.

- Availability of time: the use of cast-in-situ piles implies a longer time for excavation and casting than needed for casting a shallow option.

- Economy: Piled foundation systems are generally costlier than any shallow foundation option.

Design and economy are listed as the third and fourth main factors of shoring construction with a relative importance index of $0.75 \& 0.72$. These factors considered as a group of factor which moderately affects the construction process. Construction techniques are grouped as a factor that slightly affects the shoring work.

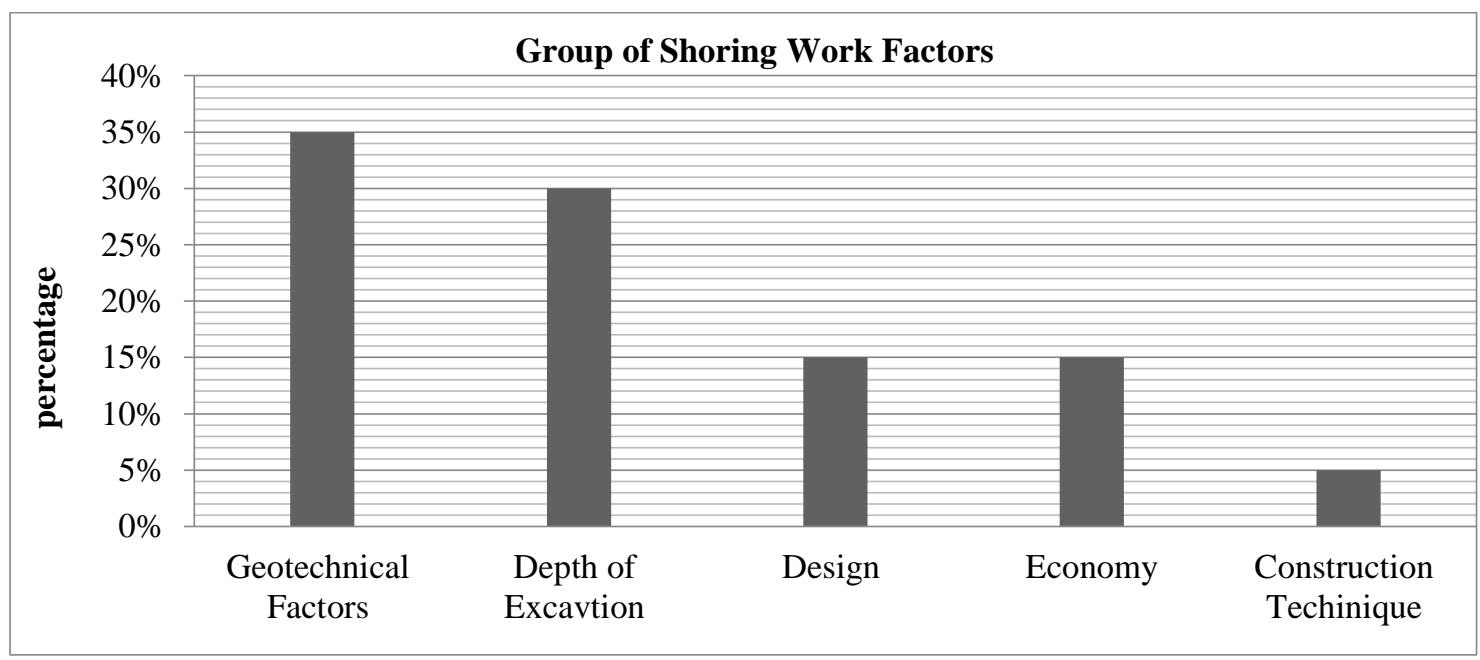

Figure 7: Major Cost Factors

C. Alternative techniques of Shoring Work

This part of the study tried to investigate and ask the respondent about the alternative material used in shoring work to decrease the cost, time, and minimize wastage during shotcrete construction. But most of the respondents (55\%) have no idea about Ferrocement, even the material type. However, in the study, awareness creation should be made about Ferro-cement as an alternative material by discussing the physical and mechanical properties. As illustrated in the first chapter, the third specific objective of the study is to recommend Ferro-cement construction in place of normal rebar will increase some industry significance. It decreases the cost of shotcrete construction by up to $20 \%$. These discussions were made based on the site visit made during data collection and interview made for two sites practicing Ferro-cement in shoring work this technique as an input.

\section{C.1 Properties of Ferro-cement}

Ferro-cement, often regarded as just another form of reinforced concrete, is unique concerning material behavior and structural applications' suitability. Ferro-cement possesses a very significant degree of toughness, ductility, durability, strength, and crack resistance that it is considerably higher than that found in other forms of concrete construction [14]. These properties are obtained in structures with a thickness that is less than $25 \mathrm{~mm}$, a dimension that is nearly improbable in other forms of concrete construction, 
and a clear improvement over conventional reinforced concrete. Some of the properties of [14] Ferro-cement were discussed below.

a) Tensile Behavior

Unlike reinforced concrete, the tensile behavior of Ferro-cement is considerably different due to its spacing that is closer and uniformly than in reinforced concrete, and its smaller diameter results in a larger specific surface area. This, in turn, affects cracking behavior (finer and number of cracks) in Ferro-cement.

\section{b) Compression Strength}

The high compressive strength of mortar materials contributes primarily to the compressive strength of the Ferro-cement composite. However, the type of reinforcement may have some influence on the compressive strength.

c) Flexural strength

An experiment conducted to study Ferro-cement's behavior, and strength in flexure found that the ultimate moment will increase with increasing matrix grade (decreasing water-cement ratio) and increasing volume fraction of reinforcement.

d) Shear

Shear strength depends on mortar, strength of wire mesh, volume fraction \& shear span.

Fatigue Resistance

Fatigue strength plays an essential role in restricting Ferro-cement in structures subjected to such a loading as in bridges. The strength of the wire, as tested in air, is the primary factor affecting fatigue of the composite.

e) Durability

When Ferro-cement is exposed to an aggressive environment, its successful performance depends greatly on its durability against the environment than on its strength properties. The external causes may be physical, chemical, or mechanical. They may be due to weathering, the occurrence of extreme temperatures, abrasion, electrolytic action, and attack by natural and industrial liquids and gases. Generally, Ferro-cement has good durability.

f) Water (or Liquid) Retaining Capacity:

Another special property to be noted was water retention when the Ferro-cement application was considered in liquid storage tanks. The significant aspect is the small crack widths so that leakage may be minimal.

\section{C.2 Advantage of Ferro-cement Construction}

Ferro-cement is a labor-intensive material that does not require compressors, pumps, or mechanical mixer used for cement and sand mixing, but may be mixed on the ground with shovels. Handwork is good quality and builds pride through solidarity, and it's also peacefully quiet.

a. Ease of Placement

It can be easily placed with minimal or no formwork. Cement slurry, the generally used bonding agent, is very cheap \& quite effective. Even though the mortar used has a very less water-cement ratio, it can still be worked onto the inverted beams.

b. Workmanship

The application of Ferro-cement jacketing does not require skilled labor. Even masons well versed with the art of cement plastering can do this job satisfactorily. Only minimal supervision will suffice the job at hand.

\section{c. Cost}

Ferro-cement uses steel wire meshes that are about 2 to 5 times cheaper by weight than ordinary steel bars. The assemblage of those meshes required medium level or non-skilled labor, which is advantageous in developing countries where labor costs are relatively low.

\section{C.3 Ferro-cement for Developing Countries}

- It may be fabricated into almost any conceivable form to meet the particular requirements of the user.

- Ferro-cement's construction's basic raw materials such as sand, cement, and reinforcing mesh are readily available in most countries.

- Except for highly stressed areas or critical structures such as deep-water vessels, adequate Ferro-cement construction does not demand stringent specifications.

- The cement should be specified its standard quality used in building construction. Special grades are unnecessary.

- Specific training is necessary for the laborers; providing a skilled supervisor is on hand.

- Cement construction techniques are widely known in developing countries, and indigenous construction workers often show a good plastering aptitude.

- Transportation, logistics, and materials-handling are serious problems in developing countries. And Ferro-cement construction simplifies each one.

- Under challenging conditions, wire mesh may be hand-loomed on-site from reels of straight wire.

\section{CONCLUSION}

Urbanization is a worldwide trend in all countries. The need for deep excavation is a result of such urbanization trends. An overview of different deep excavation support types is given for various loading, sub-soil conditions, adjacent structures, 
environmental constraints, equipment, and technical expertise availability. In the analysis and discussion part, the study has determined several factors that affect shoring work construction in CBD areas of Addis Ababa, Ethiopia. Based on the results, the following major conclusions were drawn:

a. Poor geotechnical investigation and nature of the soil

- Lack of well-trained geotechnical investigators and those who interpret that report.

- The varying nature of the soil stratum creates a difficult situation to determine the best-suited design parameter and results in uncertainty during excavation work.

- A small number of samples are taken to deduct the soil's whole soil nature around the site.

b. Design Error

- Giving little consideration for existing structure and utility while deciding the length and inclination of anchor tie-backs.

- The designer's inability to suggest an alternative soil protection method, while the current construction trend (anchor technology) becomes impractical in black cotton (expansive) soil.

- Improper spacing between anchor piles \& shotcrete fibers which will cause structural failure in the shoring system.

c. Poor construction techniques

d. A limited number of competitive firms executing shoring construction

- The higher gap between the demand from the fast-growing construction industry and the smallest firms specialized in shoring and other substructure works becomes the major cause in raising the work's cost and delaying the projects' overall progress.

- The current trend in soil protection works is highly machine-intensive and requires qualified personnel and professionals to execute the work.

- The soil stratum found in CBD areas restricted the firms from seeing alternative cost-effective soil protection methods; rather, they will be stacked with the current expensive soil protection shoring technique.

\section{ACKNOWLEDGMENT}

The authors are grateful to all the respondents that made ample support during the data collection, including our friends, especially to Mr. Mussie T. and Eng. Esayas B., anchor foundation specialists.

\section{REFERENCES}

[1] F. Murillo et al. (2009). "Urban Sector Studies and Capacity Building for Khartoum State" UN-HABITAT

[2] Garretson, P.P. (2000). A History of Addis Ababa from Its Foundation in 1886 to 1910. Otto Harrassowitz, Wiesbaden.

[3] Tesfaye, B. (1987). Addis Ababa Master Plan: Historical Development of Addis Ababa. National Urban Planning Institution, Addis Ababa.

[4] Seth Pearlman, Michael Walker, Marco Boscardin (2004). Deep Underground Basements for Major Urban Building Construction. Presented at ASCE GeoSupport 2004, Drilled Shafts, Micropiling, Deep Mixing, Remedial Methods and Specialty Foundations Orlando, Florida, Jan. 29-31, pp 1-16.

[5] F. Murillo et al. (2009). "Urban Sector Studies and Capacity Building for Khartoum State" UN-HABITAT.

[6] ESD (2011). "Report on Shoring study for Al-Tadamon Islamic Bank excavation in Khartoum," Khartoum.

[7] Wikipedia .com. http://www.latong.net/place/addis-ababa-Ethiopia [Accessed 30 Mar. 2020]

[8] Chetty, P., Correlation of variables in SPSS. [online] Project Guru. Available at: https://www.projectguru.in/correlation-variables-spss/ [Accessed 17 Oct. 2020]

[9] Rashid H. Tikote, Manisha M. Magdum, Manish A. Khandare. (2017). Delay Analysis in Industrial Projects by using Relative Importance Index Method. International Research Journal of Engineering and Technology. Vol. 04 (06), pp 1982-1988

[10] Hatkar KB and Hedaoo NA. (2016). Delay Analysis by Using Relative Importance Index Method in Infrastructure Projects, International Journal of Civil Engineering and Concrete Structures, Vol. 1, No. 3, pp 9-21.

[11] Wood, D.F., Banthia, N. and Trottier, J-F. (1993). A comparative study of different steel fibers in Shotcrete. In Shotcrete for underground support VI, New York: Am. Soc. Civ. Engrs. Niagara Falls, pp. 57- 66.

[12] Sekaran, U., \& Bougie, R. (2010). Research methods for business: A skill-building approach (5th ed.). Haddington: John Wiley \& Sons.

[13] Song Z, Deng Q, Ren Z. Correlation, and principal component regression analysis for studying air quality and meteorological elements in Wuhan, China. Environ Prog Sustainable Energy. 2020;39: e13278, pp1-11. https://doi.org/10. 1002/ep.13278

[14] Satjapan Leelatanon, Suthon Srivaro, and Nirundorn Matan. Compressive Strength and Ductility of Short Concrete Columns Reinforced by Bamboo. Songklanakarin Journal of Science and Technology, 32 (4), 2010, 419-424. 